\title{
Investigation of Lower Palaeozoic rocks in northern East Greenland
}

\section{Peter Frykman}

Field work in 1977 was carried out primarily to collect rock samples for use in establishing a biozonation based on micro-fossils for the East Greenland Cambro-Ordovician sequence described by Cowie \& Adams (1957). The most extensive sampling was done in the two type-sections of Cowie \& Adams (1957) in Albert Heim Bjerge and Ella $\varnothing$ (fig. 35) in which macro-fossils are relatively sparse.

In addition to this, an investigation was made of the virtually unexplored C. H. Ostenfeld Nunatak in the Wordie Gletscher, from which Cowie \& Adams (1957, p. 45) reported the presence of rocks belonging to the Hyolithus Creek Formation and the Cass Fjord Formation.

The East Greenland Cambro-Ordovician sequence comprises $3000 \mathrm{~m}$ of mainly carbonates with $200 \mathrm{~m}$ of clastics in the lower part. The succession of Cambrian deposits from the Kløftelv Formation to Hyolithus Creek Formation displays a gradual change from exclusively terrigenous sedimentation to a dominantly carbonate sedimentation (fig. 36). From then upwards carbonates dominate the Cambro-Ordovician sequence with only minor clastic intervals.

Fig. 35. Sketch map of northern East Greenland showing outcrops of Cambro-Ordovician sediments (in black).

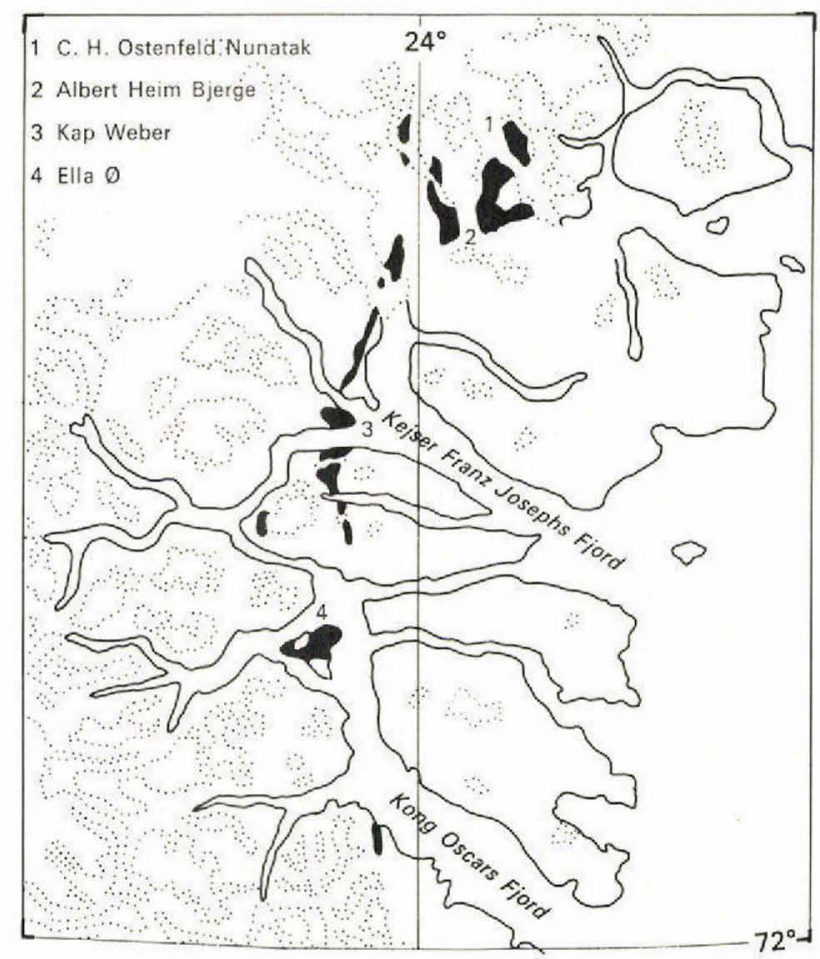




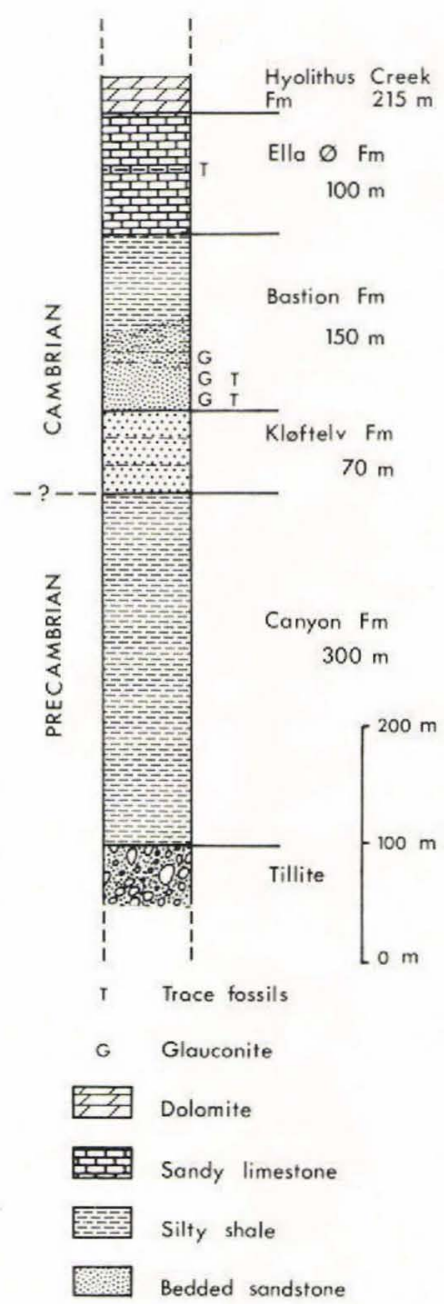

A Coarse sandstone

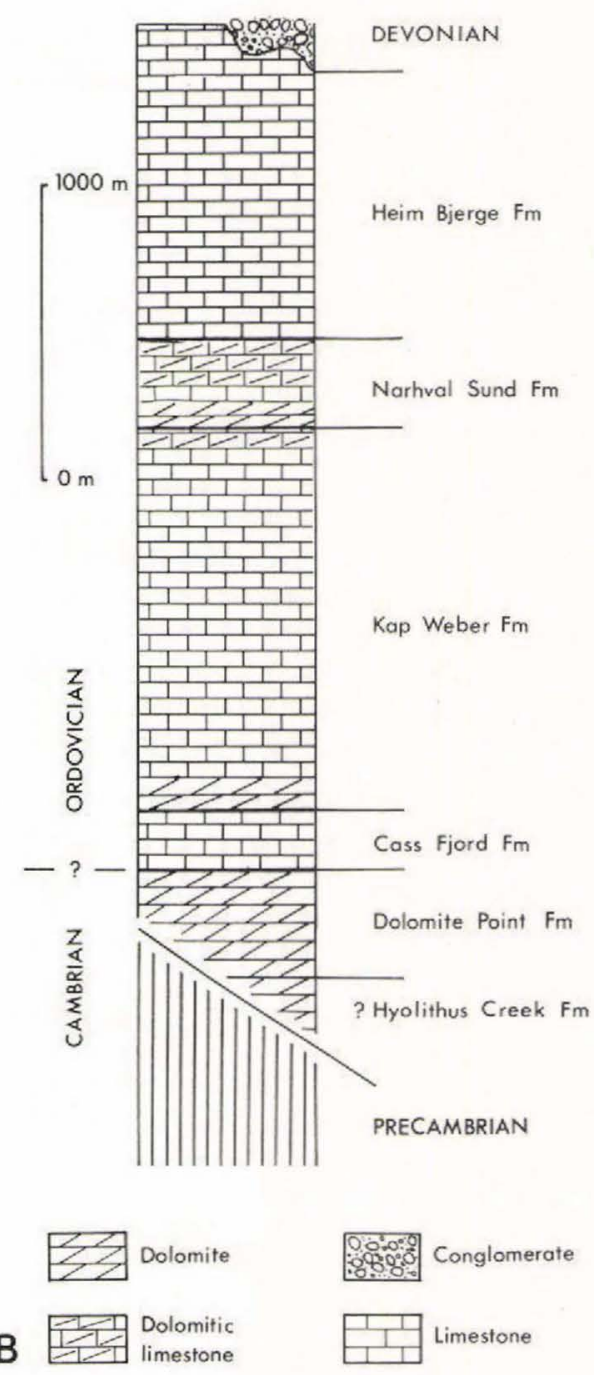

Fig. 36. Stratigraphic schemes from northern East Greenland. A: Composite section of Late Precambrian - Lower Cambrian rocks modified from Cowie \& Adams (1957); B: Cambrian-Ordovician section from C. H. Ostenfeld Nunatak.

The sequence recorded on C. H. Ostenfeld Nunatak is in general in accordance with the 'classic' localities of Cowie \& Adams (1957) further to the south, comprising the full sequence from the Hyolithus Creek Formation to the Heim Bjerge Formation (fig. 36). Indeed, the latter formation appears to have reached its thickest on this nunatak totalling more than $1000 \mathrm{~m}$ compared to the $320 \mathrm{~m}$ found in Albert Heim Bjerge. This apart, the most noticeable deviation from the development found on Ella $\varnothing$ and in Albert Heim Bjerge 
is the presence of $120 \mathrm{~m}$ of pure dolomite in the lower part of the Kap Weber Formation. A very small occurrence of Devonian conglomerates was found unconformably overlying the Cambro-Ordovician sequence.

A number of Lower Cambrian clastic sequences were investigated especially with regard to trace-fossils. The best collections originated from the lower part of the Bastion Formation in Albert Heim Bjerge and on Ella $\varnothing$. The trace-fossils in the Bastion Formation are especially abundant in thinly bedded glauconitic, micaceous sandstone and siltstone. A diverse association occurs consisting of horizontal epifaunal and infaunal constructions as well as thin vertical tubes. Somewhat higher in the Lower Cambrian, in the Ella $\varnothing$ Formation, specimens of Cruziana are frequently found on the lower surface of silty laminae intercalated at particular horizons in the mainly carbonate sequence (fig. 36).

\section{Reference}

Cowie, J. W. \& Adams, P. J. 1957: The geology of the Cambro-Ordovician rocks of Central East Greenland. Part 1. Stratigraphy and structure. Meddr Grønland 153,1 193 pp.

Institut for historisk Geologi og Palceontologi, University of Copenhagen,

$\emptyset$ ster Voldgade 10, 1350 Copenhagen $K$.

\section{Field investigations of Tertiary basic igneous rocks between $72^{\circ}$ and $73^{\circ} 30^{\prime} \mathrm{N}$, northern East Greenland}

\section{Niels Hald}

Investigations of Lower Tertiary igneous rocks of basaltic composition were undertaken in the region between Kong Oscars Fjord and Moskusoksefjord during the summer 1977. The greater part of the field season was spent in Giesecke Bjerge while shorter visits were paid to Geologfjord, Traill $\emptyset$ and the eastern part of Geographical Society $\varnothing$ (fig. 37).

\section{Giesecke Bjerge}

The pre-volcanic basement in Giesecke Bjerge is formed of extrusive and intrusive igneous, mainly acid rocks of Devonian age and by an incomplete sequence of Devonian to Cretaceous sediments (Maync, 1940, 1942, 1949; Bütler, 1954; Graeter, 1957; Koch \& Haller, 1971). The field work in 1977 has shown that quartzite conglomerates alternating with coarse-grained micaceous sandstones form the youngest member of the sedimentary sequence. These deposits have not been dated. Maync (1940) and Vischer (1943) assumed that similar material underlying the Tertiary lavas on Wollaston Forland and Hold with 